\title{
PARTICIPANTS OF RUSSIAN NAVAL EXPEDITIONS ON THE POLITICAL AND LEGAL AND SOCIO-ECONOMIC SITUATION OF THE TURKMEN OF THE EAST CASPIAN REGION (MID-18 ${ }^{\text {th }}-$ MID-19 $\left.^{\text {th }} c\right)^{1}$
}

\author{
Roman Yu. Pochekaev \\ National Research University Higher School of Economics, Saint Petersburg, Russian Federation
}

\begin{abstract}
Introduction. The aim of the paper is to study the notes of the participants of Russian naval expeditions to the east coast of the Caspian Sea since the middle of $18^{\text {th }}$ to the second half of $19^{\text {th }} \mathrm{c}$. as a source of information on the political and legal position of local Turkmen tribes. Another aim is to analyze the significance of this information for the further advance of the Russian Empire to Central Asia. Methods and materials. The sources of the study are official reports of the heads of expeditions, scientific works and, in some cases, memoirs of the participants. The methods used in the paper are critical analysis of textual sources, historical and legal study, comparative historical analysis, institutional approach. Analysis. The notes of the participants of Russian naval expeditions contain valuable and sometimes unique information on specific features of the social and political structure of nomadic tribes of the East Caspian region including the political structure of tribes, legal regulation of different fields of relations, such as trade relations, extractive activities, settlement o conflicts, etc. The comparative analysis of the notes demonstrates that by the middle of $19^{\text {th }} \mathrm{c}$. the evaluation of East Caspian nomads became more critical and strict. This reflected the views of Russian political circles on the necessity to strengthen the positions of the Russian Empire in Central Asia even by military methods. Results. Information of the participants of Russian naval expeditions is of great value as they were eye-witnesses or even participants of political, legal and socioeconomic relations in the region. These notes became a part of the informative and ideological base for the further advance of the Russian Empire to Central Asia.

Key words: Russian Empire, exploration of the Caspian Sea, Turkmenistan, Kazakhstan, traditional state and law of Eurasian nomads, travelers' notes.

Citation. Pochekaev R.Yu. Participants of Russian Naval Expeditions on the Political and Legal and SocioEconomic Situation of the Turkmen of the East Caspian Region (Mid-18 ${ }^{\text {th }}-$ Mid-19 ${ }^{\text {th }}$ c.). Vestnik Volgogradskogo gosudarstvennogo universiteta. Seriya 4. Istoriya. Regionovedenie. Mezhdunarodnye otnosheniya [Science Journal of Volgograd State University. History. Area Studies. International Relations], 2020, vol. 25, no. 5, pp. $42-51$. (in Russian). DOI: https://doi.org/10.15688/jvolsu4.2020.5.4
\end{abstract}

\section{УЧАСТНИКИ РОССИЙСКИХ МОРСКИХ ЭКСПЕДИЦИЙ О ПОЛИТИКО-ПРАВОВОМ И СОЦИАЛЬНО-ЭКОНОМИЧЕСКОМ ПОЛОЖЕНИИ ТУРКМЕН ВОСТОЧНОГО ПРИКАСПИЯ (СЕРЕДИНА ХVIII - СЕРЕДИНА ХІХ в.) ${ }^{1}$}

\author{
Роман Юлианович Почекаев \\ Национальный исследовательский университет «Высшая школа экономики», \\ г. Санкт-Петербург, Российская Федерация
}

Аннотация. Целью статьи является исследование записок участников российских морских экспедиций к восточному побережью Каспийского моря как источника сведений о политико-правовом и социально-эконо- 
мическом положении туркменских родов и племен, населявших этот регион, а также анализ значения этих сведений для продвижения России в Среднюю Азию. Источниками являются официальные отчеты руководителей экспедиций, научные сочинения участников, подготовленные по итогам экспедиций, в некоторых случаях также и воспоминания участников. Для исследования используются методы критического анализа текстов, историко-правовой, сравнительно-исторический и институциональный методы. Демонстрируется значение этих экспедиций в формировании и реализации среднеазиатской политики Российской империи, анализируются сведения участников экспедиций об особенностях политического и правового положения туркмен Восточного Прикаспия с середины XVIII до второй половины XIX века. Рассмотрены особенности социально-политической организации туркмен, вопросы правового регулирования отдельных сфер отношений - в первую очередь торговли, а также промысловой деятельности, порядок разрешения споров. Автор приходит к выводу о высокой ценности сведений участников российских морских экспедиций, поскольку они являлись непосредственными наблюдателями, а нередко и участниками политико-правовых и социально-экономических отношений среди прикаспийских туркмен. Сравнительный анализ записок участников экспедиций показывает, что ближе к середине XIX в. оценки туркмен становились все более жесткими и критическими, что отражало взгляды российских политических кругов о необходимости укрепления положения Российской империи в регионе решительными мерами, в том числе и путем прямого военного завоевания.

Ключевые слова: Российская империя, изучение Каспийского моря, Туркмения, Казахстан, традиционное государство и право кочевников Евразии, записки путешественников.

Цитирование. Почекаев Р. Ю. Участники российских морских экспедиций о политико-правовом и социально-экономическом положении туркмен Восточного Прикаспия (середина XVIII - середина XIX в.) // Вестник Волгоградского государственного университета. Серия 4, История. Регионоведение. Международные отношения. - 2020. - Т. 25, № 5. - C. 42-51. - DOI: https://doi.org/10.15688/jvolsu4.2020.5.4

Введение. Роль российского военноморского флота в присоединении Средней Азии к России в последнее время становится весьма актуальным направлением в исследованиях среднеазиатской политики Российской империи. Однако большинство специалистов сосредоточивается преимущественно на деятельности Аральской и Амударьинской флотилии в середине XIX - начале XX века. Эта тематика нашла отражение как в отдельных статьях $[5 ; 6 ; 12 ; 13 ; 21]$, так и в монографических трудах $[14 ; 15$, с. 182-208] и диссертационных исследованиях [24]. Деятельность же морских исследовательских экспедиций на восточном берегу Каспийского моря, имевших место с середины XVIII в. и в течение столетия вносивших существенный вклад в расширение представлений российских властей и научной общественности о Восточном Прикаспии, до сих пор привлекала внимание лишь специалистов по истории науки и географических открытий [16, с. 23-24, 24-25, 184; 17, с. 22-26, 32-33, 43-47; 18, с. 20, 22, 40-41].

Между тем в записках руководителей и участников морских экспедиций к восточному берегу Каспийского моря содержатся сведения о самых различных сторонах жизни местных туркмен. В рамках данной статьи автор намерен сосредоточиться на исследо- вании информации об особенностях политического положения и правового регулирования социальных и экономических отношений прикаспийских туркмен. Ценность анализируемых сведений заключается в том, что их авторы являлись свидетелями, а в ряде случаев - и непосредственными участниками политических, правовых и социально-экономических отношений в регионе. Их информация позволяет существенно расширить, в ряде случаев подтвердить, а в ряде - и скорректировать представления о политическом устройстве и правовых отношениях туркмен Прикаспия, основанные на письменных источниках, материалах этнографических исследований и пр. Кроме того, автор намерен оценить значение сведений участников морских экспедиций о туркменах для дальнейшего продвижения России в Среднюю Азию.

Методы и материалы. Источниками, анализируемыми в настоящем исследовании, являются официальные отчеты начальников морских экспедиций середины XVIII - середины XIX в., научные труды и сообщения, а в ряде случаев - и воспоминания участников. В частности, исследуются журнал инженермайора Ладыжинского, члена экспедиции капитана Толмачева 1764-1765 гг., журнал ученого К.И. Габлица - участника экспедиции 
капитана 2-го ранга М.И. Войновича 17811782 гг., записки дипломата и государственного деятеля Н.Н. Муравьева (Карского) об экспедиции 1821 г., труды ученого Г.С. Карелина об экспедициях 1832 и 1836 гг. и ряд работ его спутника по экспедиции 1836 г. капитана И.Ф. Бларамберга, воспоминания морского офицера К. Петриченко об экспедиции 1852 г., рапорты полковника Главного штаба В.Д. Дандевиля и журнал его спутника титулярного советника М.Н. Галкина об экспедиции 1859 г., наконец, сообщение контр-адмирала Н.А. Ивашинцева о промежуточных результатах его многолетних экспедиций в регионе 1856-1871 годов. Естественно, сбор сведений о государственности и праве прикаспийских туркмен не являлся главной целью экспедиций, которые основное внимание уделяли географическим, биологическим, геологическим изысканиям, интересовались возможностью развития торговых путей в Центральную Азию. Поэтому сведения политико-правового характера являются краткими и разрозненными, информации же о социально-экономическом положении туркмен в данных материалах имеется несколько больше. Их систематизация и сравнительный анализ позволяют сформировать достаточно целостное представление о некоторых сторонах политико-правовой жизни туркменских родов и племен, населявших восточный берег Каспийского моря.

Поставленная цель исследования и специфика изучаемых материалов обусловили применение ряда общих и специальных методов. Прежде всего используются метод критического анализа исследуемых текстов и синтез их сведений. Также используется историко-правовой метод, позволяющий извлечь информацию правового характера из неюридических источников. Институциональный подход помогает провести предметный анализ отдельных политических и правовых институтов у туркмен Восточного Прикаспия социально-политическая структура, регулирование заключения торговых соглашений, порядок разрешения споров и т. д. С помощью сравнительного анализа, во-первых, прослеживается эволюция в регулировании тех или иных сфер отношений (в том числе с учетом усиления российского присутствия в регионе), во- вторых, выявляются изменения в самих оценках прикаспийских туркмен, которые давали им участники морских экспедиций в разное время. Анализ сведений о политико-правовом и социально-экономическом положении туркмен Восточного Прикаспия осуществляется с позиций правового плюрализма, в рамках которого признается значимость и ценность любых правовых систем вне зависимости от их принадлежности к «европейским» или «традиционным» правовым семьям.

Анализ. Российские морские экспедиции к восточному берегу Каспия начались еще в первой четверти XVIII в. и были связаны с активизацией политики Петра I в Прикаспийском регионе в целом. Однако разгром хивинцами экспедиции кн. А. Бековича-Черкасского в 1717 г. произвел настолько шокирующее впечатление на имперские властные круги, что исследовательская деятельность в Восточном Прикаспии прервалась на несколько десятилетий [9, с. 319]. Лишь с 1760-х гг. морские экспедиции вновь стали отправляться в Восточный Прикаспий и с этого времени периодически осуществлялись в течение целого столетия, до начала 1870-х гг., когда они фактически утратили актуальность в связи с завоеванием Средней Азии и возможностью организации «сухопутных» экспедиций под патронажем руководства вновь созданного Туркестанского генерал-губернаторства.

Ценные наблюдения делают участники морских экспедиций по поводу социально-политического устройства туркмен. Прежде всего они отмечают раздробленность туркменских племен, в результате которой не только племена, но даже и отдельные роды в их составе нередко вели самостоятельную политику и, более того, признавали подданство разных государств. Так, родовые подразделения туркменских племен теке, гокланов, эрсари признавали власть персидских шахов, хивинских ханов, либо же являлись независимыми $[4$, с. 79,107$]$.

Представители имперской администрации, привыкшие взаимодействовать с казахскими ханами и султанами, единолично выступавшими от имени своих многочисленных подданных, с удивлением узнавали, что звание ханов у туркмен ничего не значит. В результате по тем или иным вопросам приходи- 
лось договариваться не то что с каждым племенем или родом, но даже с каждым отдельным аулом [7, с. $71 ; 19$, с. 599]. Уже инженермайор Ладыжинский в середине XVIII в. отмечал, что у туркмен нет правителей, и все решения принимают родовые старшины [10, с. 786]. Именно старшины представляли интересы туркменских племен и родов в отношениях с Россией в XVIII в., выступая в том числе и посредниками между Россией и среднеазиатскими ханствами по дипломатическим и торговым вопросам [11, с. 94-95]. Но И.Ф. Бларамберг в 1830-х гг. отмечал, что и старшины не пользовались значительным влиянием, и туркмены признавали власть лишь семейных старейшин-аксакалов и в особенности собственных отцов [4, с. 109; 19, с. 599]. Впрочем, при отправлении в набег или же снаряжении каравана туркмены выбирали себе предводителей, которым подчинялись: согласно К. Петриченко, любое решение такого «начальника отряда» выполнялось беспрекословно [19, с. 598-599].

Неудивительно, что наиболее энергичные и амбициозные туркменские лидеры старались изыскивать разные средства для повышения авторитета среди соплеменников. Наиболее распространенным среди них являлась демонстрация покровительства со стороны иностранных правителей. Некоторые туркменские ханы и старшины носили хивинские или персидские титулы, другие же старались заручиться наградами от русских. И.Ф. Бларамберг вспоминал о встрече с туркменом, имевшим благодарственное письмо еще от М.И. Войновича, «засвидетельствованное» также Н.М. Муравьевым [2, с. 75]. М.Н. Галкин также упоминает, что некоторые старшины еще и в середине XIX в. гордились «свидетельствами», полученными от Войновича [7, с. 86]. Г.С. Карелин сам в рапортах оренбургским властям рекомендовал наградить нескольких туркменских старшин, оказавших ему содействие, которые в конечном счете получили от имперской администрации золотые или серебряные медали и серебряные сабли [23, № 181-182, с. 269 , № 184 , с. 270 ].

В некоторых случаях поддержка России оказывалась и более эффективной. Так, в 1821 г. Н.Н. Муравьев призвал туркмен признать власть вышеупомянутого Кият-хана, в результате чего тому удавалось в течение нескольких десятилетий контролировать значительную часть многочисленных и обычно разрозненных туркменских родов и племен Восточного Прикаспия и обеспечивать мирные отношения с Россией [8, с. 416-417; 22, с. $182-$ $183]^{2}$. Его сын Язши-Мурад даже получил европейское образование в Тифлисе [3, с. 6; 22 , с. 204]. Неудивительно, что впоследствии участники русских экспедиций сожалели, что после смерти Кият-хана между туркменами вновь начались междоусобицы, что ухудшило и их отношения с Россией [23, № 351, с. 481].

Большую ценность представляют сведения участников морских экспедиций об отношениях с туркменами в сфере торговли, поскольку позволяют оценить уровень развития тех или иных сфер правоотношений и правовых институтов у прикаспийских кочевых племен. Поскольку туркмены Восточного Прикаспия вели активную торговлю с соседними государствами, у них значительное развитие получили договорные отношения. Так, М.Н. Галкин вспоминает, что во время переговоров о предоставлении экспедиции Дандевиля верблюдов туркмены весьма скрупулезно обсуждали цену найма животных и вознаграждения их погонщикам [7, с. 107-108].

Еще более подробно описывается регулирование отношений в сфере рыбной ловли и торговли рыбой (в первую очередь осетриной), которая для большинства кочевников восточного берега Каспия являлась единственным источником дохода $[10$, с. $784 ; 23$, № 351 , c. 479] ${ }^{3}$. В XVIII - начале XIX в., согласно запискам участников морских экспедиций, речь шла просто о ловле рыбы и ее продаже русским или персидским торговцам, в том числе и просто проезжавшим через их владения [3, с. 42]. Для отправки в Персию рыбакам приходилось нанимать суда $[11$, с. $94 ; 22$, c. 294]. Но уже в первой трети XIX в. отношения в этой сфере существенно усложняются: туркмены заключают с российскими и персидским партнерами договоры о передаче им в аренду своих рыболовных владений на откуп на определенный срок [22, с. 237-238]. Согласно И.Ф. Бларамбергу первым из русских такой договор с туркменами заключил астраханский купец А. Герасимов [4, с. 105], но затем права на аренду перекупил другой астра- 
ханец М.-А. Багиров, перс по происхождению, являвшийся к тому же купцом первой гильдии [20, с. 127]. Однако впоследствии Багиров, как сообщает Г.С. Карелин, не поладил с владельцами рыболовных мест, и Герасимов восстановил с ними договор. Этот договор, согласно Карелину, был заключен с соблюдением всех необходимых формальностей: оформил его казий - мусульманский судья, Герасимов и туркменские старшины поставили свои подписи, затем договор был заверен самим Карелиным как представителем российских властей $[3$, с. $21 ; 22$, с. $276,292-$ 293, 297, 322-323].

Впрочем, нельзя не отметить, что отношения, связанные с рыбной ловлей, нередко страдали из-за аламанов - традиционных набегов с целью захвата добычи и рабов: туркмены совершали самые настоящие морские пиратские набеги на русских рыбаков (доходя даже до западного берега Каспия), захватывая суда и пленников. По сведениям Г.С. Карелина, из 1500 лодок, имевших официальное разрешение («билет») на рыбную ловлю от астраханских властей, за два года более 200 было захвачено туркменами [8, c. $394-395 ; 22$, с. 154,157$]$. Со временем русские рыбопромышленники, стремясь уменьшить риск захвата их работников, стали комплектовать экипажи наполовину русскими, наполовину - представителями мусульманских народов, в частности, татарами. Однако последние, как сообщает тот же Карелин, порой сами же захватывали собственных православных спутников и продавали их туркменам [22, c. 157-158]. Подобные случаи существенно подрывали рыболовную промышленность в Каспийском море и снижали эффективность экономических связей российских рыбопромышленников с прикаспийскими туркменами.

Еще одним источником дохода местных кочевников являлась нефть, богатые запасы которой путешественники отмечают на о. Челекен [19, с. 579]. По сообщению Н.Н. Муравьева, ежегодно до 20 тыс. пудов нефти продавалось в персидский Мазандеран [8, с. 239240]. Поначалу, как и в торговле рыбой, туркмены не располагали транспортом для доставки нефти, и этим пользовались российские и персидские торговцы. Но уже в 1830-е гг., как отмечает Г.С. Карелин, туркмены обза- велись собственными кораблями - «киржимами», что существенно снизило прибыли русских судовладельцев [22, с. 232, 460]. В периоды обострения отношений с Персией туркмены пытались продавать нефть русским, но при этом, как сообщает тот же Карелин, требовали по 2 реала за пуд, хотя она стоила всего 1,5 , так что сделки не осуществлялись [22, с. 342].

Право собственности на нефтяные месторождения у туркмен не было четко регламентировано. И.Ф. Бларамберг сообщает, что «главные колодцы принадлежат трем хозяевам и переходят из рода в род». При этом никакими документами их права не подтверждались и основывались лишь на «изустных преданиях». Более того, любой желающий также имел право вырыть колодец на острове, не встречая ни от кого противодействия $[4, \text { c. } 70]^{4}$.

Сходная ситуация складывалась и в сфере соляного промысла. Н.Н. Муравьев в 1821 г. сообщает о наличии больших залежей соли на том же Челекене, но, поскольку у персов в Астрабаде имеются собственные соляные озера, эту соль туркменам продавать не удается [8, с. 239]. Однако вскоре ситуация изменилась, и уже в 1830-е гг., по свидетельству Г.С. Карелина, туркмены доставляли соль, как и нефть, кораблями в Мазандеран, где персидские купцы покупали ее оптом и потом в розницу продавали по всей Персии. Развитие соляной промышленности привело к тому, что некоторые туркменские вожди, по примеру персов, стали собирать «десятинную пошлину» с привозной соли [22, с. 235,294$]$. Однако на самом Челекене право собственности на соляные копи также было весьма неопределенным: М.Н. Галкин упоминает, что прииски принадлежали некоему Менглы-Дурды-хану, однако тут же отмечает, что сами местные жители могут добывать соль и пользоваться ею совершенно бесплатно [7, c. 74]. Все это позволяет сделать вывод, что институт частной собственности на природные ресурсы у туркмен не получил широкого развития, и они зачастую рассматривались как общинная собственность ${ }^{5}$.

Тем не менее, если страдали имущественные интересы туркмен, то существовали различные способы разрешения противоречий. Г.С. Карелин упоминает, что один тур- 
кмен-йомуд, не получив долг с астраханского торговца-перса, захватил его, севшее на мель, судно с четырьмя моряками. Он же описывает, как вышеупомянутый сын Язши-Мурад одолжил персидскому сановнику 3000 реалов, а тот попытался вернуть ему лишь 300 реалов, а также всучить саблю и нож, вместе не стоившие и 40 реалов. Несмотря на свою «европейскую образованность», сын Киятхана повел себя как истинный туркмен: с презрением отказался и пообещал отомстить [22, с. 205, 266]. Вообще же, как писал И.Ф. Бларамберг, многие подобные споры кончались ударами кинжала [2, с. 64].

Энергично защищая свои интересы, прикаспийские туркмены не считали зазорным посягать на чужое имущество, поскольку это, как и аламан, считалось проявлением удальства. Бларамберг вспоминал, что во время переговоров о торговле несколько туркменских старшин попытались украсть несколько шкур, на которых сидели, когда же их задержали и уличили, они всего лишь заявили, что «пошутили» $[2$, с. $62 ; 3$, с. 20]. Также, в отличие от других кочевых народов, у туркмен не был развит закон гостеприимства: как сообщает Г.С. Карелин, они были готовы ограбить любого своего постояльца [22, с. 301].

Подобные проявления особенностей правосознания туркмен находили отражение и в торговле, где они всячески старались надуть «чужих». Г.С. Карелин описывает, как владелец рыбных заводей, желая получить большую выгоду по договору с А. Герасимовым, потребовал выплатить ему причитающуюся сумму (4 000 руб.) не русскими деньгами, а персидскими реалами, которых он был готов подождать еще год - при условии увеличения суммы на 50 \%. И лишь когда Карелин его «припугнул», тот согласился принять русское серебро [22, с. 301-302]. К. Петриченко сообщает, что когда один туркмен пообещал продать рыбу другому, но продал ее русскому торговцу, предложившему более высокую цену, несостоявшийся покупатель стал жаловаться - но не на продавца, а на русского торговца [19, с. 599]. Согласно рапорту В.Д. Дандевиля, туркменские старшины поставили ему верблюдов, однако ночью шайка туркмен напала на его лагерь, захватила пленников и отогнала табун, причем среди нападавших были даже и несколько продавцов верблюдов [23, № 351, с. 480]. К «чужим» туркмены относили и представителей других туркменских же племен. Так, инженер-майор Ладыжинский вспоминал, что когда прибрежные туркмены попытались начать торговлю с экспедицией, взятый на корабль проводник из другого племени отговорил ее участников от ведения дел с этими туркменами, заявив, что «они все плуты» [10, с. 787].

Подобные примеры формировали не слишком хорошее представление о личных качествах и правовых представлениях туркмен у российских путешественников. Н.Н. Муравьев характеризовал население Мангышлака как «воровское поколение» $[8$, с. 247]. И.Ф. Бларамберг отмечал, что со времени Муравьева они к лучшему не изменились, оставшись по-прежнему алчными и способными на «всякого рода низости», а мягкое к ним отношение считают за слабость [4, c. 110]. Последующие российские экспедиции учли этот опыт и стали весьма жестко реагировать на грабительские действия туркмен. Особенно ярко это проявилось во время экспедиции В.Д. Дандевиля, который не только с оружием отбивал нападения грабителей, но и сам предпринимал карательные рейды на их селения за их «неслыханную дерзость» [23, № 352, с. 482]. Н.А. Ивашинцев также давал понять, что пришла пора действовать более решительно, поскольку, по его словам, неудачи экспедиций А. Бековича-Черкасского и М.И. Войновича «произошли от одной причины, а именно от доверчивости русских к азиятцам, происходящей конечно от малого знакомства с характером народа, с которым они имели дело» [9, с. 319]. Все чаще поднимался в записках участников экспедиций вопрос о целесообразности возведения российского укрепления в Красноводском заливе (которое в результате и было возведено в 1869 г.).

Вообще, нельзя не отметить, что по мере расширения знаний о туркменских родах и племенах Восточного Прикаспия члены морских экспедиций в своих записках все более настойчиво проводили мысль о необходимости более решительных действий российских властей в регионе, тогда как оценка политико-правового и социально-экономического положения туркмен, особенностей их отно- 
шения к России становилась все более критической. Думаем, не случайно эта тенденция стала проявляться в то же время, когда Россия начала активизировать свою политику на среднеазиатском направлении. Именно к этому периоду относятся походы оренбургского губернатора В.А. Перовского на Хиву в 1839-1840 гг. и Ак-Мечеть в 1852 г., действия оренбургских и западносибирских властей по формированию пограничной линии на границах с Хивинским и Кокандским ханствами, а также принятие киргизов в российское подданство в $1850-$ е гг. и т. д.

В то же время в записках 1830-1860-х гг. все чаще обращается внимание на перспективность Восточного Прикаспия в качестве торгового маршрута в Среднюю Азию, пагубность контроля караванных дорог кочевниками, неэффективность использования ими своих природных богатств. Тут нельзя не вспомнить, что именно в этот период представителями и властных структур, и предпринимательских кругов разрабатывалось большое число проектов организации русской торговли в Средней Азии, так что и акцентирование путешественниками внимания на таких вопросах также вряд ли можно счесть совпадением.

Таким образом, участники экспедиций (многие из которых совершались по распоряжению как раз пограничных властей империи) в своих записках выражали общие настроения ряда российских властных и общественных кругов, подкрепляя их рекомендации собственными практическими наблюдениями.

Результаты. Анализ сведений участников российских морских экспедиций к восточному берегу Каспийского моря о политикоправовом и социально-экономическом положении туркменских племен позволяет сделать следующие выводы.

Во-первых, особенности социально-политического устройства туркмен, отмеченные участниками морских экспедиций, предполагали существенные изменения в формате взаимоотношений с ним, которые раньше строились по образу и подобию отношений с другими кочевниками - в частности, с казахами. Отсутствие у туркмен института верховной власти, номинальное главенство их ханов и старшин заставляло представителей Российской империи расширять круг партнеров по переговорам со стороны туркмен, изыскивать новые средства заинтересовать их в мирных и дружественных отношениях с Россией, договариваясь с отдельными родами, предоставляя льготы в торговле и пр.

Во-вторых, у туркмен Прикаспия были достаточно четко регламентированы частноправовые отношения, в особенности в таких сферах, как торговля и добыча полезных ископаемых, а также порядок решения имущественных споров. Однако при взаимодействии с ними в этих сферах российским представителям приходилось все время адаптироваться к особенностям «традиционного» правосознания и правопонимания, любые же попытки русских путешественников и торговцев действовать в соответствии с принципами и нормами «европейских» частноправовых отношений оказывались неэффективными.

Наконец, в-третьих, ближе к середине XIX в. цели экспедиций все более смещались от научно-исследовательских к военным. Соответственно, реакция на враждебные действия прикаспийских туркмен со стороны экспедиций становилась все более жесткой, а в отчетах и записках их участников критика кочевников, их неуправляемости, «разбойничьего» образа жизни и враждебности по отношению к России становится все более жесткой, все чаще говорится о необходимости стабилизации положения в Восточном Прикаспии военными методами. Такой подход был напрямую связан с тем, что определенные круги Российской империи - в первую очередь, пограничные администрации Кавказского наместничества и Оренбургского края, а также руководившее ими Военное министерство все более настойчиво выступали за активизацию российского продвижения в Среднюю Азию. Учитывая вышеупомянутую подчиненность руководства и участников морских экспедиций пограничным властям и, соответственно, принадлежность к военному ведомству, не приходится удивляться, что они и в своих записках старались отражать соответствующую позицию.

Таким образом, можно утверждать, что сведения участников морских экспедиций к восточному берегу Каспийского моря о политико-правовом и социально-экономическом положении местных туркменских племен, с 
одной стороны, являются важным источником по истории государственности и права кочевников региона, с другой же - представляют ценность и как отражение идеологии сторонников решительной среднеазиатской политики Российской империи, которая активно стала реализовываться как раз с середины XIX века.

\section{ПРИМЕЧАНИЯ}

${ }^{1}$ Исследование выполнено за счет гранта Российского научного фонда (проект № 19-18-00162), реализуемого в Институте языков и культур имени Льва Толстого.

The study was supported by the grant of the Russian Science Foundation (project No. 19-18-00162) implemented at the Leo Tolstoy Institute of Languages and Cultures.

${ }^{2}$ Конечно же, не следует считать, что вольнолюбивые прикаспийские туркмены с готовностью последовали исключительно призыву российского дипломата. Просто пребывание Н.Н. Муравьева в Восточном Прикаспии совпало с очередным обострением отношений местных туркмен с Хивинским ханством и Персией, и, признав власть сторонника России, они рассчитывали на ее поддержку в случае вооруженного конфликта. Неудивительно, что сам Кият-хан и его сыновья за приверженность к России вызывали гнев персидских и хивинских властей и на некоторое время были вынуждены переселиться на о. Челекен [4, с. 72-73].

${ }^{3}$ Не случайно персидские власти, стремясь взять под контроль прикаспийских туркмен, время от времени предпринимали попытки захвата принадлежавших им рыбных мест на побережье [1, с. 126-127].

${ }^{4}$ При этом любопытно отметить, что богатые месторождения каменного угля на Челекене, в отличие от нефти, не становились предметом интереса ни туркмен, ни их торговых партнеров: Н.А. Ивашинцев и в 1869 г. характеризовал их всего лишь как «подающие надежду на разработку» [9, c. 318].

${ }^{5}$ Вероятно, именно поэтому не дали результата упоминаемые М.Н. Галкиным попытки англичан приобрести несколько участков земли у туркмен [7, с. 70, 105].

\section{СПИСОК ЛИТЕРАТУРЫ}

1. Аминов, И. И. Организационно-правовые основы становления и развития российско-туркменских отношений (1714-1917 гг.) / И. И. Аминов. М. : Юрлитинформ, 2017. - 344 с.
2. Бларамберг, И. Ф. Воспоминания / И. Ф. Бларамберг.-М. : Изд-во вост. лит., 1978. - 357 с.

3. Бларамберг, И. Ф. Журнал, веденный во время экспедиции для обозрения восточных берегов Каспийского моря в 1836 г. / И. Ф. Бларамберг // Записки Императорского Русского географического общества. - 1850. - Т. 4. - С. 1-48.

4. Бларамберг, И. Ф. Топографическое и статистическое описание восточного берега Каспийского моря от Астрабадского залива до мыса ТюкКараган / И. Ф. Бларамберг // Записки Императорского Русского географического общества. - 1850. T. 4. - C. 49-120.

5. Васильев, А. Д. Амударьинская флотилия и ее роль в истории Центральной Азии / А. Д. Васильев // Восточный архив. - 2015. - № 2 (32). - С. 14-16.

6. Васильев, А. Д. Участие морского ведомства в Ахал-текинской экспедиции / А. Д. Васильев // Восточный архив. - 2014. - № 1 (29). - С. 15-18.

7. Галкин, М. Н. Этнографические и исторические материалы по Средней Азии и Оренбургскому краю / М. Н. Галкин. - СПб. : Изд. Я. А. Исакова, 1868. $-\mathrm{V}+336 \mathrm{c}$.

8. Записки Н.Н. Муравьева-Карского, 1821 год, вторая поездка в Закаспийский край // Русский архив. - 1888. -Кн. 1.- С. 235-258, 393-432.

9. Ивашинцев, Н. А. Сообщение о восточном береге Каспийского моря по отношению к торговым путям, ведущим в Среднюю Азию / Н. А. Ивашинцев // Известия Императорского Русского географического общества. - 1869. - Т. 5. - С. 317-320.

10. Извлечение из журнала инженер-майора Ладыжинского, посыланного в 1764 году для осмотра восточных берегов Каспийского моря // Акты, собранные Кавказской археографической комиссией. - Т. 6, ч. 2. - Тифлис : Типография главного управления Наместника кавказского, 1875. - С. 783-797.

11.К.Г. [Габлиц, К. И.] Исторический журнал бывшей в 1781 и 1782 годах на Каспийском море российской эскадры под командою флота капитана второго ранга графа Войновича / К. И. Габлиц. - М. : Типография С. Селивановского, 1809. XXVIII $+120 \mathrm{c}$.

12. Кадырбаев, А. Ш. Материалы Российского государственного архива Военно-Морского флота об изучении и освоении Аральского моря российскими военными моряками / А. Ш. Кадырбаев // Восточный архив. - 2003. - № 10. - С. 63-71.

13. Кадырбаев, А. Ш. Народы Приаралья в середине XIX века (по письмам А. И. Бутакова 18481849 гг.) / А. Ш. Кадырбаев // Восточный архив. 2006. - № 14-15. - С. 65-71.

14. Каторин, Ю. Ф. Андреевский флаг над барханами. Участие российских моряков в завоевании Средней Азии / Ю. Ф. Каторин. - СПб. : Гангут, 2018. - 208 c. 
15. Кучирь, А. Г. Каспийское мореходство - дело государево. История борьбы за Каспий / А. Г. Кучирь. - СПб. : Балтийская книжная компания, 2015.$216 \mathrm{c}$.

16. Материалы для истории экспедиций Академии наук в XVIII и XIX веках. Хронологические обзоры и описание архивных материалов / сост. В. Ф. Гнучева. - М. ; Л. : Изд-во АН СССР, 1940.$312 \mathrm{c}$.

17. Обзор русских путешествий и экспедиций в Среднюю Азию / сост. О. В. Маслова. - Ч. 1. 17151856. - Ташкент : Изд-во САГУ, 1955. - 84 с.

18. Обзор русских путешествий и экспедиций в Среднюю Азию / сост. О. В. Маслова. - Ч. 2. 1856 1869. - Ташкент : Изд-во САГУ, 1956. - 102 с.

19. Петриченко, К. Рассказы каспийского моряка / К. Петриченко // Русский вестник. - 1857. T. 9. - C. 575-600.

20. Пирова, Р. Н. Персидское купечество и астраханская таможня в первой половине XIX века / Р. Н. Пирова // Исторические, философские, политические и юридические науки, культурология и искусствоведение. Вопросы теории и практики. - 2016. - № 12 (74), ч. 3. - С. 126-128.

21. Почекаев, Р. Ю. А.И. Бугаков и Аральская флотилия в конще 1840-х - начале 1860-х гг. / Р. Ю. Почекаев // Вопросы истории. - 2015. - № 4. - С. 142-150.

22. Путешествия Г. С. Карелина по Каспийскому морю // Записки Императорского Русского географического общества по общей географии. 1883. - T. 10. - VI + 497 c.

23. Русско-туркменские отношения в XVIIIXIX вв. (до присоединения Туркмении к России). Ашхабад : АН Туркменской ССР, 1963. - 585 с.

24. Сулайманов, С. А. История Аральской и Амударьинской флотилий (1847-1920 гг.) : автореф. дис. ... канд. ист. наук / Сулайманов Саламат Арепбаевич. - Нукус, 2010. - 25 с.

\section{REFERENCES}

1. Aminov I.I. Organizatsionno-pravovye osnovy stanovleniya i razvitiya rossiysko-turkmenskikh otnosheniy (1714-1917 gg.) [Organizational and Legal Foundations of the Establishment and Development of Russian-Turkmen Relations (1714-1917)]. Moscow, Yurlitinform Publ., 2017. 344 p.

2. Blaramberg I.F. Vospominaniya [Memories]. Moscow, Izd-vo vostochnoy literatury, 1978. 357 p.

3. Blaramberg I.F. Zhurnal, vedennyy vo vremya ekspeditsii dlya obozreniya vostochnykh beregov Kaspiyskogo morya v 1836 g. [Journal Kept During the Expedition to Survey East Coasts of the Caspian Sea in 1836]. Zapiski Imperatorskogo Russkogo geograficheskogo obshchestva, 1850, vol. 4, pp. 1-48.
4. Blaramberg I.F. Topograficheskoe i statisticheskoe opisanie vostochnogo berega Kaspiyskogo morya ot Astrabadskogo zaliva do mysa Tyuk-Karagan [Topographic Account of the East Coast of the Caspian Sea from Astrabad Gulf to Tyuk-Karagan Cape]. Zapiski Imperatorskogo Russkogo geograficheskogo obshchestva, 1850, vol. 4, pp. 49-120.

5. Vasilyev A.D. Amudaryinskaya flotiliya i ee rol v istorii Tsentralnoy Azii [Amudaria Flotilla and Its Role in the History of the Central Asia]. Vostochnyy arkhiv, 2015, no. 2 (32), pp. 14-16.

6. Vasilyev A.D. Uchastie morskogo vedomstva $\mathrm{v}$ Akhal-tekinskoy ekspeditsii [Participation of Navy in the Akhal-Teke Expedition]. Vostochnyy arkhiv, 2014, no. 1 (29), pp. 15-18.

7. Galkin M.N. Etnograficheskie i istoricheskie materialy po Sredney Azii i Orenburgskomu krayu [Ethnographic and Historical Materials on Central Asia and Orenburg Region]. Saint Petersburg, Izd-vo Ya.A. Isakova, 1868 . V $+336 \mathrm{p}$.

8. Zapiski N.N. Muravyeva-Karskogo, 1821 god, vtoraya poezdka $\mathrm{v}$ Zakaspiyskiy kray [Notes of N.N. Muravev-Karskiy, 1821, Second Journey to the Trans-Caspian Region]. Russkiy arkhiv, 1888, book 1, pp. 235-258, 393-432.

9. Ivashintsev N.A. Soobshchenie o vostochnom berege Kaspiyskogo morya po otnosheniyu k torgovym putyam, vedushchim v Srednyuyu Aziyu [Report on the East Coast of the Caspian Sea Concerning the Trade Routes Leading to Central Asia]. Izvestiya Imperatorskogo Russkogo geograficheskogo obshchestva, 1869, vol. 5, pp. 317-320.

10. Izvlechenie iz zhurnala inzhener-mayora Ladyzhinskogo, posylannogo v 1764 godu dlya osmotra vostochnykh beregov Kaspiyskogo morya [Extract from the Journal of Major-Engineer Ladyzhinskiy Sent in 1764 to Observe the East Coasts of the Caspian Sea]. Akty, sobrannye Kavkazskoy arkheograficheskoy komissiey. T. 6, ch. 2 [Acts Collected by Caucasian Archaeographic Comission. Vol. 6, Part 2]. Tiflis, Tipografiya glavnogo upravleniya Namestnika kavkazskogo, 1875, pp. 783-797.

11. Gablits K.I. Istoricheskiy zhurnal byvshey v 1781 i 1782 godakh na Kaspiyskom more rossiyskoy eskadry pod komandoyu flota kapitana vtorogo ranga grafa Voynovicha [Historical Journal of the Stay of the Russian Squadron Under the Command of Commander Count Voynovich in the Caspian Sea in 1781 and 1782]. Moscow, Tipografiya S. Selivanovskogo, 1809. XXVIII $+120 \mathrm{p}$.

12. Kadyrbaev A.Sh. Materialy Rossiyskogo gosudarstvennogo arkhiva Voenno-Morskogo flota ob izuchenii i osvoenii Aralskogo morya rossiyskimi voennymi moryakami [Materials of the Russian State Archive of the Russian Navy on Exploration and 
Developing of the Aral Sea by Russian Men-of-War]. Vostochnyy arkhiv, 2003, no. 10, pp. 63-71.

13. Kadyrbaev A.Sh. Narody Priaralia v seredine XIX veka (po pismam A.I. Butakova 1848-1849 gg.) [Peoples of Aral Region in the Middle of $19^{\text {th }}$ Century (Based on Letters of A.I. Butakov of 1848-1849)]. Vostochnyy arkhiv, 2006, no. 14-15, pp. 65-71.

14. Katorin Yu.F. Andreevskiy flag nad barkhanami. Uchastie rossiyskikh moryakov $v$ zavoevanii Sredney Azii [St. Andrews Flag Over the Barkhans. Participation of Russian Men-of-War in the Conquest of Central Asia]. Saint Petersburg, Gangut Publ., 2018. 208 p.

15. Kuchir A.G. Kaspiyskoe morekhodstvo-delo gosudarevo. Istoriya borby za Kaspiy [Caspian Navigation - Sovereigns Business. History of the Struggle for the Caspian Sea]. Saint Petersburg, Baltiyskaya knizhnaya kompaniya, 2015.216 p.

16. Gnucheva V.F., ed. Materialy dlya istorii ekspeditsiy Akademii nauk v XVIII $i$ XIX vekakh. Khronologicheskie obzory $i$ opisanie arkhivnykh materialov [Materials for History of Expeditions of the Academy of Sciences in $18^{\text {th }}$ and $19^{\text {th }}$ Centuries. Chronological Reviews and Descriptions of Archival Materials]. Moscow, Leningrad, Izd-vo AN SSSR, 1940. 312 p.

17. Maslova O.V., ed. Obzor russkikh puteshestviy i ekspeditsiy v Srednyuyu Aziyu. Ch. 1. 1715-1856 [Survey of Russian Travels and Expeditions to Central Asia. Part 1. 1715-1856]. Tashkent, Izd-vo SAGU, 1955. 84 p.

18. Maslova O.V., ed. Obzor russkikh puteshestviy i ekspeditsiy v Srednyuyu Aziyu. Ch. 2.
1856-1869 [Survey of Russian Travels and Expeditions to Central Asia. Part 2. 1856-1869]. Tashkent, Izd-vo SAGU, 1956. 102 p.

19. Petrichenko K. Rasskazy kaspiyskogo moryaka [Tales of the Caspian Seaman]. Russkiy vestnik, 1857, vol. 9, pp. 575-600.

20. Pirova R.N. Persidskoe kupechestvo i astrakhanskaya tamozhnya $\mathrm{V}$ pervoy polovine XIX veka [Persian Merchants and Astrakhan Customs in the First Half of the $19^{\text {th }}$ Century]. Istoricheskie, filosofskie, politicheskie i yuridicheskie nauki, kulturologiya $i$ iskusstvovedenie. Voprosy teorii $i$ praktiki, 2016, no. 12 (74), part. 3, pp. 126-128.

21. Pochekaev R.Yu. A.I. Butakov i Aralskaya flotiliya $\mathrm{v}$ kontse $1840-\mathrm{kh}$ - nachale $1860-\mathrm{kh}$ gg. [A.I. Butakov and Aral Flotilla at the End of 1840 s Beginning of 1860s]. Voprosy istorii, 2015, no. 4, pp. 142-150.

22. Puteshestviya G.S. Karelina po Kaspiyskomu moryu [Travels of G.S. Karelin to the Caspian Sea]. Zapiski Imperatorskogo Russkogo geograficheskogo obshchestva po obshchey geografii, 1883, vol. 10. $\mathrm{VI}+497 \mathrm{p}$.

23. Russko-turkmenskie otnosheniya v XVIII$X I X v v$. (do prisoedineniya Turkmenii $k$ Rossii) [Russian-Turkmen Relations in $18^{\text {th }}-19^{\text {th }} \mathrm{c}$. (Before Joining of Turkmenistan to Russia)]. Ashkhabad, AN Turkmenskoy SSR, 1963. 585 p.

24. Sulaymanov S.A. Istoriya Aralskoy $i$ Amudarinskoy flotiliy (1847-1920 gg.): avtoref. dis. ... kand. ist. nauk [History of Aral and Amudaria Flotillas (1847-1920). Cand. hist. sci. diss. abs.]. Nukus, $2010.25 \mathrm{p}$.

\section{Information About the Author}

Roman Yu. Pochekaev, Candidate of Sciences (Jurisprudence), Associate Professor, Professor, Head of the Department of Theory and History of Law and State, National Research University Higher School of Economics, Promyshlennaya St, 17, 198099 Saint Petersburg, Russian Federation, rpochekaev@hse.ru, https://orcid.org/0000-0002-4192-3528

\section{Информация об авторе}

Роман Юлианович Почекаев, кандидат юридических наук, доцент, профессор, заведующий кафедрой теории и истории права и государства, Национальный исследовательский университет «Высшая школа экономики», ул. Промышленная, 17, 198099 г. Санкт-Петербург, Российская Федерация, rpochekaev@hse.ru, https://orcid.org/0000-0002-4192-3528 